\section{Referees unmasked?}

SIR - The present climate of open decisionmaking in science has been reflected in the printing of signed editorials in British Medical Journal (3 October 1981). Surely now is the time to consider alternatives to the traditional policy of anonymity for the referees of learned journals.

The problems which can arise from such a policy have disturbed authors for many years. Recently (Nature 25 June 1981, p.608), it has been suggested that the disclosure of the names of the referees to authors would avoid corruption and injustices. The alternative, that the names of authors and institutions be withheld from referees (Nature 30 July 1981, p.402), has obvious flaws and double-blind evaluation (Nature 17 September 1981, p.293) is unlikely to be attained.

The publication of the names of the referees would give recognition to their responsibility and we feel would lead to an improvement in the standard of published work. At best, a referee can make a valuable contribution to a manuscript, which deserves open

acknowledgement in the published paper. Conversely the cursory examination of research work has resulted in the growth in number of papers of dubious merit, despite editorial vigilance. Responsibility for the appearance of such publications should be shared by the referees and their names no longer concealed.

\section{D.J. LEA} H. SHEPPEARD

Robert Jones \& Agnes Hunt

Orthopaedic Hospital, Oswestry, UK

\section{Migration fund?}

$\mathrm{S}_{\mathrm{R}}$ - What practical steps are we going to take to aid our Russian colleagues who are not allowed to leave their country (see letter from Dikii et al., Nature 24/31 December 1981, p.688)? Perhaps we should look more closely at why the Soviet government refuses to let them leave; one feels that there must be some governmental reason for the actions that are taken - it cannot, one hopes, be simply a whim of some highly placed individual.

The Soviet government could argue that it has invested heavily in the education of scientists and cannot afford to waste this investment. But the response to an application to emigrate is the withdrawal of scientific employment and the investment is lost anyway. Perhaps the Soviet government sees the use of this scientific education in another country as a double loss, and opts for what it sees as the better of two bad choices.

Interested governments, involved in scientific migrations, might press UNESCO or some similar body (the International Council of Scientific Unions perhaps) to set up a "Migrant Scientists Fund". This hard currency fund would be used to alleviate some of the injustices caused by scientific migration. For example, a country which loses a scientist could receive monetary compensation; the country to which he goes, which at the moment receives a gift of all that expensive education and training, would pay into the fund. This would benefit many countries, in particular the poorer countries which scientists tend to leave, and should prove no hardship to the rich countries to which they go. New Zealand attracts qualified people, but also loses quite a number; on balance we would probably be drawing from the fund. Australia would contribute.

In the case of the Soviet Union the flow is essentially one way, immigration to the country is on a very small scale. The fund could recompense the Soviet government for its lost educational investment and this might be a welcome source of hard currency. Countries which wish to encourage the movement of scientists could actually donate to the fund.

\section{New Zealand Soil Bureau,}

Lower Hutt, New Zealand

IAN SMALLEY

\section{Vide the Latin}

SIR - In the leading article, page 389 in your issue of 3 December 1981, entitled "Tolerance but not quarter for creationists", it is asserted that "creationism is not a part of science but an alternative to it".

As the word science is derived from the Latin scire, to know, would it not have been nearer the truth to apply this statement to the theory of evolution? While making no claim to vast knowledge of things existing, as I consider such known things as the cochlea, or the lens of the eye, or three-dimensional perception, I find creationism truly essential to science. A great mind expressed this in Romans $\mathrm{Ch} .1 \mathrm{v}$. 20:- "The invisible things of God from the creation of the world are clearly seen, being understood by the things that are made, even his eternal power and Godhead."

D.H.T. CONWAY

Weymouth, Dorset, UK

\section{Areas of neglect}

SIR - I have been following with great and increasing interest the profound cogitations on creationism in your respected columns.

However, it is a pity that these discussions have been restricted to a particular field of biology. Surely there are many other sciences that need a thorough overhaul to put them into agreement with divine revelation. Take astronomy for example. It is high time that the godless Newtonian theories should be expelled and the Earth returned to its lawful place at the centre of the Universe.

Another science tha is singularly deficient is psychology. Modern t.xtbooks never mention the well-documented scientific facts of manipulation of the human mind by devils. Surely some enlightened state administrators should provide the necessary funds for an experimental investigation of these important phenomena. In this respect we have fallen far behind what was known in the Middle Ages, when at least a number of practical and efficient iniethods were in use for dealing with Satanic influences.

As a final example one could cite acoustics.
The most important application of this branch of physics - the demolition of city walls by sound waves - is no longer a fashionable subject of study, although new findings in the field of surface acoustic waves could provide a solution to this problem. It is a sad reflection on the state of present-day science that students never hear of it, except through a well-known negro spiritual.

S.V. VAECK

Brussels, Belgium

\section{DNA and Europe}

SIR - The article by Jasper Becker on the EEC safety dispute concerning recombinant DNA (Nature 24/31 December 1981, p.686) gives a quite correct picture of the situation. But Jasper Becker states that the socialists are in favour of a community directive. This is not quite correct. The socialist group in the European parliament has never voted on this question. Only the socialist members of the environment committee have given their opinion. Other members of the group, like me, have a different position for a multitude of reasons. In my view, only industrial and agricultural applications of recombinant DNA work should be regulated at an EEC level.

Fritz Gautier (MEP)

Socialist Group,

Braunschweig/Brussels, Belgium

\section{Brief encounter}

SIR - In your summary "Hoyle on Evolution"' (Nature 12 November 1981, p.105) you cite Hoyle as saying that for higher life forms to have emerged by chance is comparable to the chance that a tornado sweeping through a junk-yard will assemble the material into a Boeing 747 .

This reminds me of a debate I had some years ago with Dr Douane Gish of the San Diego Institute of Creation Research. The occasion was a symposium in Utrecht organized by the Evangelische Omroep, the Dutch Evangelical Broadcasting Company. This company broadcasts the creationist message for several hours per week to Dutch audiences via television and radio. At the symposium in Utrecht I defended the theory of biological evolution, and Dr Gish defended the biological aspects of creationism. During the discussion Dr Gish remarked that the chance that amino acids would spontaneously form biologically active protein molecules was practically zero. I then said: "Dr Gish, if somebody had asked me on the day of my birth to calculate the chance that one day I would have a debate in Utrecht with Dr Gish from San Diego, I would have answered that this chance was practically zero. Am I therefore to understand that you are not $\mathrm{Dr}$ Gish from San Diego?' But my opponent had the perfect answer to that one. He said: "I am not here by chance, I was invited!" 